
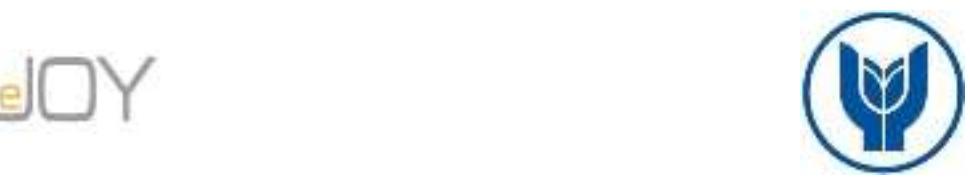

Solunoğlu, A. / Journal of Yasar University, 2020, 15/60, 833-849

\title{
Perceived Food Quality, Satisfaction, Brand Image In Restaurants And Recommendation Intention Relation
}

\author{
Restoran İşletmelerinde Algılanan Yemek Kalitesi, Memnuniyet, Marka İmajı \\ Ve Tavsiye Etme Davranışı İlişkisi
}

\author{
Ali SOLUNOĞLU, Turkey, alisolunoglu@msn.com
}

Orcid No: 0000-0003-0232-8248

\begin{abstract}
In this study, the interaction in between recommendation intention and perceived food quality, satisfaction, brand image is examined. The relations among stated variables are statistically analysed with structural equation modelling. Conceptual framework is formed by having literature review and a questionnaire is applied to 361 consumers dined at Köfteci R. restaurant located in İmir, with convenience sampling method. In the study, descriptive (percentage, average, standard deviation) and predictive statistics methods are used. Also, structural equation model is benefited to test the relation among latent variables. In the light of acquired results, it has been identified that food quality positively and strongly affects the brand image, satisfaction and recommendation intention. In addition to this, it has been also identified that consumer satisfaction has significant and positive effect on brand image and recommendation intention. The research has been concluded with the recommendation to various stakeholders and other researchers in the light of acquired results.
\end{abstract}

Key words: Food Quality, Satisfaction, Marketing, Restaurants, Structural Equation Modelling

JEL Classification: L83, M31, Z31

Öz: Bu araştırmada restoran işletmelerinde algllanan yemek kalitesi, memnuniyet, marka imajı ve tavsiye etme davranışının birbirleri ile olan etkileşimleri irdelenmiştir. Bu amaçla ifade edilen değişkenler arasındaki ilişkiler yapısal eşitlik modellemesi kullanılarak istatistiksel analize tabi tutulmuştur. Literatür taraması yapılarak kavramsal çerçeve oluşturulmuş ve kolayda örnekleme yöntemi ile İzmir'de Köfteci R. restoran işletmesinde yemek yiyen 361 tüketiciye anket uygulanmıştır. Çalışmada tanımlayıcı (yüzde, ortalama, standart sapma) ve tahminleyici istatistik yöntemleri kullanılmıştır. Ayrıca gizil/örtük değişkenler arasındaki ilişkilerin test edilmesi amacıyla yapısal eşitlik modelinden yararlanılmıştır. Elde edilen sonuçlar doğrultusunda tüketici tercihlerinde yemek kalitesinin marka imajını, memnuniyeti ve tavsiye etme davranışını pozitif yönde güçlü düzeyde etkilediği belirlenmiştir. Bunun yanı sıra tüketici memnuniyetinin tavsiye etme davranışı ile marka imajı üzerinde anlamlı ve pozitif yönlü etkileri olduğu belirlenmiştir. Araştırma, elde edilen sonuçlar ışığında çeşitli paydaşlar ve diğer araştırmacılara öneriler ile tamamlanmıştır.

Anahtar Kelimeler:Yemek Kalitesi, Memnuniyet, Pazarlama, Restoranlar, Yapısal Eşitlik Modellemesi

JEL Siniflandirmast: L83, M31, Z31

\section{Introduction}

Food and beverage enterprises in service industry with an incrementally increasing in number and serving to a wide range of customers from different social-economic levels, are required to meet the customer expectations and demands in order to survive in competition environment, increase the revenue and have sustainability of enterprise operability.

\section{Makale Geçmiși / Article History}

Başvuru Tarihi / Date of Application : : 7 Nisan / April 2020

Kabul Tarihi / Acceptance Date : : 26 Haziran / June 2020

(c) 2020 Journal of Yaşar University. Published by Yaşar University. Journal of Yaşar University is an open access journal.

There is no conflict of interest or ethical concern regarding this publication. 
Restaurant managers who would like to be successful are required to create a pleasant service atmosphere and provide the best service to their customers. However, socio-economic conditions, and health rules of customers make it necessary to serve food and beverage services based on conscious and scientific ground rather than a random service (Türksoy 2007: 4; Lin and Mattila, 2010). As a matter of fact, it is not enough to meet the physical needs of customers at the enterprises where food and beverage service is provided. There is also the necessity of providing an environment in which customers enjoy atmosphere by meeting their emotional, intellectual and spiritual needs, have pleasant time, save time and relax (Harrington, Ottenbacher and Treuter, 2015; Longart, Wickens and Bakir, 2017; Badem and Öztel, 2018). In this manner, the likelihood of increased customer experience quality and continuation of choosing the restaurants that sustain the quality in question will increase.

Perceived quality of restaurant experience by customers can be composed of different dimensions. The importance of the product quality, service quality and value (Albayrak, 2015; Muscat, Hörtnagl, Prayag and Wagner, 2019), the product range and price factor as well as the restaurant features should be emphasized in the scope of these dimensions (Jiang and Rosenbloom, 2004; Küçükergin and Dedeoğlu, 2014; Gül and Gül, 2016). In many researches studying the customers' intention to novelty-seeking it is concluded that food quality and menu/food diversity is important (Clark and Wood, 1999; Soriano, 2002; Barta, 2008; Bekâr and Gövce, 2019) decor, seats and exterior design factors represent importance in restaurant preferences (Ryu, Lee and Kim, 2012; Bekâr and Sürücü, 2015) and restaurant atmosphere and customer experience are other factors (Ha and Jang, 2013).

Also it is seen that food quality has effect on perceived value and customer satisfaction; perceived value and customer satisfaction positively affects customer loyalty (Wirtz, Mattila and Tan, 2000; Lin, 2010; Bengül and Güven, 2019) restaurant image has positive effect on perceived value, satisfaction and behavioural intentions (Ryu, Han and Kim, 2008) perceived service quality has significant relationship with restaurant image and brand trust $(\mathrm{Hu}$, Kandampully and Juwaheer, 2009; Jin, Lee and Gopalan 2012; Uslu and Karabulut, 2019) and customer satisfaction is effective on behavioural intentions (Chen and Chen 2010; Bujisic, Hutchinson and Parsa 2014; Karakaş, Bilgin and Kıngır 2017). In this manner, restaurant preferences and customer behaviours are examined in different aspects in many studies.

In line with the acquired results, it is considered that service quality and other factors are evaluated all together in the mind of a customer and it has effect on dimensions of satisfaction, brand image, perceived value, satisfaction and behavioural intentions. As a 
matter of fact, overall outcomes of customer experience quality should be considered as the operational success report of an enterprise, an organization or a unit. While the successful ones will be able to improve the sustainable processes, the failed ones will have to endure costs or even worse consequences to revise operational activities.

In the current study, the interaction among food quality, satisfaction, brand image and recommendation intention which are the dimensions of perceived experience quality as believed to have an impact on restaurant preferences will be examined in accordance with the results of other researches. In this manner, tips will be provided for the sector representatives on the issues to be attentive in their enterprises and also a possibility of having holistic analysis will be offered to academicians interested in the topic.

\section{Conceptual Framework}

\subsection{Food Quality}

Food quality is the most important component of an overall restaurant experience (Sulek and Hensley, 2004) and it is an essential requirement to meet the expectations and needs of restaurant customers (Peri, 2006). Many customers have knowledge on food, and the taste of food at restaurants has gained much higher importance (Cortese, 2003). Food quality and fresh ingredients are among the most important factors underlying the preference of a restaurant again (Soderlund and Rosengren, 2008). That's why, it is not surprising for a restaurant with good food quality to have intense demand from customers. Jin, Lee and Huffman (2012) have stated in their study that restaurant's food quality has direct impact on brand image. In that study, significant interactions between perceptions about the quality of the food served to customers in restaurants and brand image have been identified. In the light of the literature studies mentioned above, the first hypothesis of the research was developed as follows;

H1: There is a significant positive relation between food quality and brand image.

Generally, food quality affects the satisfaction of restaurant customers and their future behavioural intentions (Yuksel 2001; Rozekhi, Hussin, Siddiqe, Rashid and Salmi, 2016) and satisfied customers show the intention to revisit the restaurant (Sulek and Hensley, 2004). Clark and Wood (1998) state that food quality is the crucial determinant of customer loyalty. Food quality is the essential component of customer satisfaction among restaurant experiences when compared with environment and service qualities (Sulek and Hensley, 2004). In studies where the food quality and customer satisfaction are examined, a positive relation has been identified (Namkung and Jang, 2007; Huang and Shanklin, 2008; Ha and 
Jang, 2010). Also, food quality renders the customer and brand relationship permanent, provides the continuity of purchase intention and contributes to the enterprise's being recommended to others, as well (Bowden, 2009, Jeong and Jang, 2011; Parsa, Self, Gregory and Yoon, 2012). Food quality affecting directly the restaurant image is important for perceived value and satisfaction of customers. The studies in the literature show that this situation has effect on behavioural intentions, as well (Kandampully and Suhartanto, 2000; Ryu and et.al. 2008). In this manner, the hypotheses were developed as follows:

$\mathrm{H} 2$ : There is a positive significant relation between food quality and customer satisfaction.

H3: There is a positive significant relation between food quality and recommendation intention.

\subsection{Satisfaction}

Customer satisfaction preserves its importance as a subject studied by researches in the relational marketing literature (Qin and Prybutok, 2008; Jang and Namkung, 2009; Ryu and et al., 2012). Because satisfaction is the most important determinant of purchase intention (repurchasing, opting brand and preferring) (Tsiotsou, 2006). In the study of Han and Ryu (2009), "The roles of the physical environment, price perception, and customer satisfaction in determining customer loyalty in the restaurant industry", customer satisfaction is defined as a general assessment of perceived inconsistency between the previous expectation and real consumption. The overall assessment affects the repurchase intent and behaviour and also can reduce or increase the future revenue and profit shares of businesses. High corporate loyalty and customer satisfaction are considered as a more important goal than short-term profit to be achieved economically (Keiningham and Vavra, 2001). Because satisfaction is an important factor in the increase of market share that will affect the financial performance of the enterprise, as well (Han and Ryu, 2009). This is also very important for improving the brand image and stimulating the recommendation behaviour.

Many studies in the literature show that enterprises that provide superior service quality have a more satisfying customer base (Aaker and Jacobson, 1994; Gilbert, Veloutsou, Goode and Moutinho, 2004; Gilbert and Veloutsou, 2006; Qin and Prybutok, 2009). In addition, satisfied customers tend to use a service more often than those who are not satisfied (Bolton and Lemon, 1999). These customers have higher intention to repurchase, as well as recommending the service that they are satisfied, to their acquittances (Zeithaml, Berry and Parasuraman, 1996). Promotion of a brand as a result of the recommendation intention is an important step. Kim, $\mathrm{Ng}$ and Kim (2009) found a positive relationship between the 
satisfaction of restaurant customers and their intention to revisit, while Struebing (1996) stated that the interest of new customers was more easily attracted by word-of-mouth advertising and that they were able to generate a significant income rise by increasing the number of customers who have the revisiting intention. Romaniuk and Sharp (2003) found the positive relation between brand image and customer satisfaction. Many scholars, such as Yang (2002), Lin (2005), Chen (2005) and Zhang (2007), also confirmed the positive relations between brand image and customer satisfaction. Yang (2002) proposed that customer satisfaction referred to the pleasant attitude when a customer accepting certain deal or service; and, customer satisfaction and brand value appeared notably positive relation. In line with the conclusions deriving from the literature review, the following hypotheses were developed;

H4: There is a positive significant relation between customer satisfaction and brand image.

H5: There is a positive significant relation between customer satisfaction and recommendation intention.

\subsection{Brand Image and Recommendation Intention}

The brand owned by an enterprise enables the establishment of reciprocal relationships with customers. A strong brand represents a product that makes it easy to be distinguished and respected (Perry and Wisnom III, 2004). Dobni and Zinkhan (1990) defined the brand image as a subjective and perceptual phenomenon, which is either causal or emotional, deriving from customer comments. Brand image is expressed as consumer thoughts and experiences on a given brand (Gülsoy, 1999). Brand image, which has ever-increasing importance in consumer intention-oriented researches, also affects subjective perceptions of individuals, their value, satisfaction and behavioural intentions (Jin, Lee and Huffman, 2012).

Brand image is the positive and negative emotions that can be controlled by strengths and weaknesses of the brand in the consumer's mind. These perceived emotions are formed as a result of experiences. Brands have their own unique taste, smell, texture, sound and visual identities to be preferred by leaving a permanent mark in the minds of the target audiences. Brand name, slogan and logo form the basis of the brand image. The customer's personal attributes affect the brand image and shape it. Therefore, brand image plays an important role especially in cases where it is difficult to differentiate products or services based on physical quality features (Mudambi, Doyle and Wong, 1997).

The level of satisfaction determines the decision of new customers to decide whether to repurchase the service or to recommend it to others. Experienced customers, however, are 
less sensitive to the current service and the satisfaction arising from the utilization of the service in question. Because the enterprise has created a reliable image in the eye of these customers (Brunner, Stöcklin and Opwis, 2008). Kim et al. (2009) stated that the recommendation received from the family, friends and colleagues who left the enterprise with satisfaction, had a positive effect on sales. In the related study, a high correlation was found between satisfaction and recommendation intention. Customers with corporate loyalty are those who are less likely to change the received service but willing to pay more and reflect positive experiences to their circle and tend to embrace negative situations (Zeithaml et al., 1996). Also, the brand image for these customers is a strong indicator of loyalty. On the other hand, the brand image is based only on the suggestions of their family and friends for customers who have not previously purchased services from the enterprise and is considered not to be very reliable (Brunner et al., 2008; Kim et al., 2009). Because enterprises with a positive brand image are more likely to achieve a repurchase via customer satisfaction. In the light of the above-mentioned information, the final hypothesis of the research was developed follows:

H6: There is a positive significant relation between brand image and recommendation intention.

Pine and Gilmore (1998) emphasized that creating a different customer experience can bring tremendous financial value to companies. Encouraging these experiences has become the main focus of the hospitality industry, because many products in the hospitality industry are experiential and can be classified as "overall experience" (Williams, 2006). In addition, the relationship between customer experience and brand image is inseparably linked with organizational success in the restaurant industry (Kim and Kim, 2004).

\section{Research Method}

\subsection{Aim and Method of Research}

In this study, in line with the information obtained from the literature, it is aimed to determine which dimensions related to restaurant experiences of consumers have what kind of effects on their behaviors. For this reason, the interactions between consumers' perception of food quality, satisfaction, brand image and recommendation intention in restaurant experiences are examined. In this regard, data were collected via the questionnaires applied to 361 volunteer respondents who had a dining experience at various time intervals (at noon and dinner times) at Köfteci R., in Izmir, in October - December 2019, and it is targeted to present the correlations among findings in a structural model. 
Descriptive (percentage, mean, standard deviation) and predictive statistical methods were used in the analysis of the data. In addition, structural equation modeling was preferred in order to test the relations among four variables. The questionnaire consists of two parts. In the first part, there are questions on demographic characteristics like respondents' age, gender, occupation, etc. In the second part, "Food Quality Scale, Brand Image Scale, Satisfaction Scale" which Jin, Lee and Huffman (2012) used in their study "Impact of Restaurant Experience on Brand Image and Customer Loyalty: Moderating Role of Dining Motivation" and "Scale of Recommendation Intention" which Fu and Parks used in (2001) their studies were adapted to this study and used. Items were measured using a five-point Likert scale $(1=$ strongly disagree, $3=$ neither agree nor disagree, $5=$ strongly agree $)$. All scales adopted from the literature were subjected to validity and reliability analysis.

\subsection{Data Reorganization and Analysis}

The data obtained with the help of the survey technique were coded into the SPSS program before analysis, missing value and outlier analysis were performed, and as a result, 13 questionnaire forms were removed from the data set. After this process, the data obtained from the remaining 348 questionnaire forms were rearranged. Structural equation models (SEM) analyse the skewness and kurtosis values in order to control whether the data have a normal distribution (Tabachnick and Fidell, 2012: 79). In addition, the Cronbach Alpha value of the scales used, and the confirmatory factor analysis of each scale were also examined. In the SEM configured in line with the literature review, first order unifactorial confirmatory factor analysis was performed.

\section{Findings}

\subsection{Demographic Characteristics}

Demographic findings on 348 respondents are presented in Table -1 .

Table 1. Findings on Demographic Features

\begin{tabular}{ccclcc}
\hline Age & No. & $\%$ & \multicolumn{1}{c}{ Profession } & No. & $\%$ \\
\hline 18-25 age & 80 & 23,0 & Civil servant & 104 & 29,9 \\
\hline 26-33 age & 88 & 25,3 & Private sector & 110 & 31,6 \\
\hline 34-41 age & 80 & 23,0 & Freelance & 48 & 13,8 \\
\hline 42-49 age & 73 & 21,0 & Retired & 17 & 4,9 \\
\hline 50 and above & 27 & 7,8 & Not working & 43 & 12,4 \\
\hline & & & Other & 27 & 7,5 \\
\hline Income & No. & $\%$ & Education & No. & $\%$ \\
\hline 2020 TL and less & 58 & 16,7 & Primary School & 66 & 19,0 \\
\hline 2021-3500 TL & 137 & 39,4 & High School & 133 & 38,2 \\
\hline
\end{tabular}




\begin{tabular}{cccccc}
\hline 3501-4500 TL & 106 & 30,5 & University & 126 & 36,2 \\
\hline $4501+$ TL & 47 & 13,5 & Master's Degree & 23 & 6,6 \\
\hline Sex & No. & $\%$ & Marital Status & No. & $\%$ \\
\hline Female & 215 & 61,8 & Single & 135 & 38,8 \\
\hline Male & 133 & 38,2 & Married & 213 & 61,2 \\
\hline Total & 348 & 100 & & 348 & 100 \\
\hline
\end{tabular}

When Table- 1 is examined, it is seen that $25.3 \%$ are in the age range of $26-33 ; 39.4 \%$ are in the income range of 2021-3500TL; $61.8 \%$ are women; $31.65 \%$ work in private sector, $38.2 \%$ are high school graduates and $61.2 \%$ are married.

\subsection{Normal Distribution, Validity and Reliability Analysis Results}

According to the findings of the normal distribution, validity and reliability analysis of the data obtained to determine which dimensions related to restaurant experiences of consumers have what kind of effects, whether the data used in the research has normal distribution can be evaluated based on the kurtosis and skewness values (Tabachnick and Fidell, 2012: 79). Accordingly, while these values are within the range of +/- 1.0 or $+/-1.5$ for some researchers (Bayram, 2010: 49), for others if sig is $<0.01$, it is accepted in the range of $+/$ 2.58 or sig <0, 05 is reported to be accepted in the range of $+/-1.96$ (Hair et al., 2009: 72; Altın, Kurtoğlu and Kartal, 2017) and for other researches it is accepted in the range of +/- 3 or +/- 2 (Kalayc1, 2009: 6). Descriptive statistics for items are shown in Table 2.

Table 2. Findings on Data Distribution and Reliability

\begin{tabular}{|c|c|c|c|c|c|c|c|c|c|c|c|}
\hline \multirow[t]{2}{*}{ Factors } & \multirow[t]{2}{*}{ Items } & \multirow{2}{*}{\multicolumn{2}{|c|}{ N Mean. }} & \multirow[t]{2}{*}{$\begin{array}{l}\text { Std. } \\
\text { Dev. }\end{array}$} & \multicolumn{2}{|c|}{ Skewness } & Kurtosis & \multirow[t]{2}{*}{$\begin{array}{l}\text { Stand. } \\
\text { Factor } \\
\text { loading }\end{array}$} & \multirow[t]{2}{*}{$\begin{array}{l}\text { Cron } \\
\text { bach } \\
\text { Alfa }\end{array}$} & \multirow{2}{*}{\multicolumn{2}{|c|}{ CR AVE }} \\
\hline & & & & & $\begin{array}{c}\text { Std. } \\
\text { Error }\end{array}$ & & $\begin{array}{l}\text { Std. } \\
\text { Error }\end{array}$ & & & & \\
\hline \multirow{3}{*}{ 兽 } & $\begin{array}{c}\text { Food } \\
\text { Quality1 }\end{array}$ & 348 & 3,09 & 1,290 &,- 083 &, 131 & $-1,031$ & 261 ,870 & & & \\
\hline & $\begin{array}{c}\text { Food } \\
\text { Quality2 }\end{array}$ & 348 & 3,09 & 1,285 &,- 047 &, 131 & $-1,031$ & 261, 912, &, 891 & 0,893 & $3 \quad 0,737$ \\
\hline & $\begin{array}{c}\text { Food } \\
\text { Quality3 }\end{array}$ & 348 & 2,83 & 1,255 & , 186 & ,131 &,- 971 & 789, 261, & & & \\
\hline \multirow{3}{*}{ 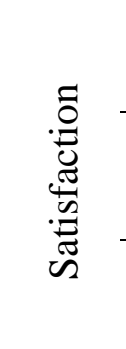 } & $\begin{array}{c}\text { Satisfactio } \\
\mathrm{n} 1\end{array}$ & 348 & 3,51 & 1,413 &,- 378 &, 131 & $-1,375$ & 902, 261, & & & \\
\hline & $\begin{array}{c}\text { Satisfactio } \\
\text { n2 }\end{array}$ & 348 & 3,73 & 1,390 &,- 699 & ,131 &,- 981 & ,843, &, 825 & 0,919 & ,793 \\
\hline & $\begin{array}{c}\text { Satisfactio } \\
\text { n3 }\end{array}$ & 348 & 3,74 & 1,104 &,- 604 & ,131 &,- 981 & 925, 261, & & & \\
\hline
\end{tabular}


Solunoğlu, A. / Journal of Yasar University, 2020, 15/60, 833-849

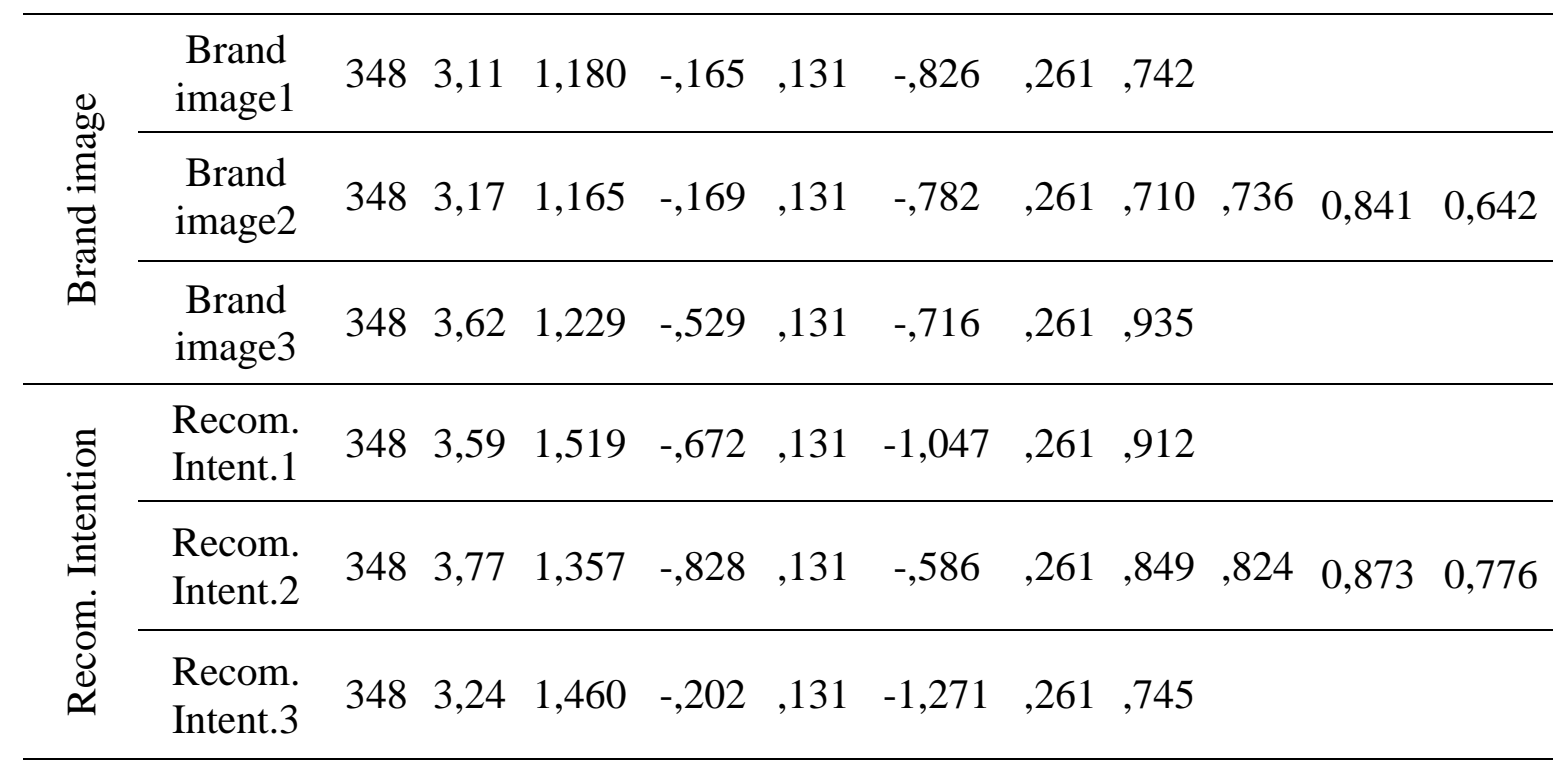

In the validity and reliability analysis, it was observed that the Cronbach's Alpha values of the scales were in the range of $0.70-0.90$. These values show that the scales are quite reliable (Kalayc1, 2009). Furthermore, it was found that the kurtosis and skewness values of the scales were within the range of $+/-2$ and the data of each variable had multiple normal distribution. In order to measure whether these distributions are validated by the data obtained, first-order unifactorial confirmatory factor analyses (CFA) were performed, and the overall model was applied by verifying the data. Also, AVE values for each variable were above 0.50 (minimum 0.64 ), and the composite reliability values (CR) were above 70 (minimum 0.841). This shows that the construct is reliable. Findings related to the overall model are presented in Figure 1. 


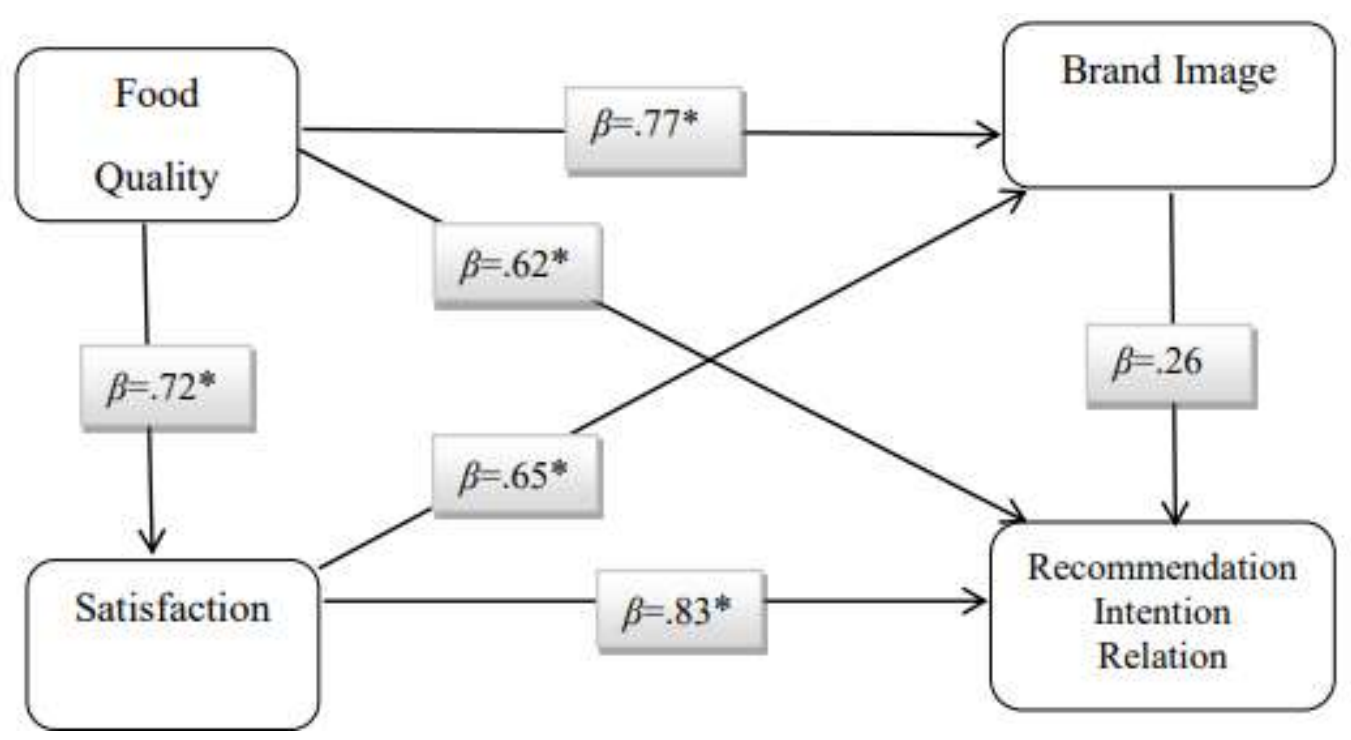

Figure 1. Structural Equation Model on Relationships Among Food Quality, Satisfaction, Brand Image and Recommendation Intention of Respondents

The data obtained to be tested via the structural equation modeling were designed in accordance with the findings in the literature and the theoretical background and then path analyses were performed. While the food quality is the exogenous variable in the constructed model, the satisfaction and the brand image are both endogenous and exogenous. The recommendation intention is the endogenous variable. The goodness of fit indices and the acceptability of the model are presented in Table 3.

Table 3. Fit Indices of Structural Equation Models and the Analysis Results

\begin{tabular}{|c|c|c|c|}
\hline $\begin{array}{l}\text { Measurement } \\
\text { (Fit Statistics) }\end{array}$ & $\begin{array}{l}\text { Goodness of } \\
\text { Fit Indices }\end{array}$ & $\begin{array}{c}\text { Acceptable Fit } \\
\text { Indices }\end{array}$ & $\begin{array}{c}\text { SEM Analysis } \\
\text { Values }\end{array}$ \\
\hline $\begin{array}{c}\text { Overall Model Fit } \\
\text { CMIN/df, }\left(\chi^{2 / d f}\right)\end{array}$ & $\leq 3$ & $\leq 4-5$ & 2,075 \\
\hline $\begin{array}{c}\text { Comparative Fit Indices } \\
\text { NFI } \\
\text { CFI } \\
\text { RMSEA }\end{array}$ & $\begin{array}{l}\geq 0,95 \\
\geq 0,95 \\
\leq 0,05\end{array}$ & $\begin{array}{l}0,94-0,90 \\
0,94-0,90 \\
0,06-0,08\end{array}$ & $\begin{array}{l}, 962 \\
, 980 \\
, 056\end{array}$ \\
\hline $\begin{array}{c}\text { Absolute Fit Indices } \\
\text { GFI } \\
A G F I\end{array}$ & $\begin{array}{l}\geq 0,90 \\
\geq 0,90\end{array}$ & $\begin{array}{l}0,89-0,85 \\
0,89-0,85\end{array}$ & $\begin{array}{l}, 956 \\
, 928\end{array}$ \\
\hline
\end{tabular}

In Table 3 showing the Goodness of Fit Indices of the Structural Equation Model, it is seen that the values obtained are acceptable. Since the goodness of fit indices of the obtained model are $\chi^{2}$ / df: 2,075, RMSEA: 0,056, NFI: 0,972, CFI: 0,980, GFI: 0,956, RMR: 0,071, it is observed that the measurement model has good fit indices. 
The path analysis results and standardized regression values of the relationships among the variables in the constructed model are presented in Table 4.

Table 4. Analysis Results of Structural Equation Model and Relationships Among Variables

\begin{tabular}{ccccc}
\hline \multicolumn{2}{c}{ Relation between variables } & $\begin{array}{c}\text { Standardized } \\
\beta\end{array}$ & $\begin{array}{c}P \\
\text { Value }\end{array}$ \\
\hline $\begin{array}{c}\text { Brand Image } \\
\text { Satisfaction }\end{array}$ & $\longleftarrow$ & Food Quality &, 779 & 0,000 \\
\hline $\begin{array}{c}\text { Recommendation } \\
\text { Intention }\end{array}$ & $\longleftarrow$ & Food Quality &, 726 & 0,003 \\
\hline $\begin{array}{c}\text { Recommendation } \\
\text { Intention }\end{array}$ & $\leftarrow$ & Food Quality &, 625 & 0,000 \\
\hline $\begin{array}{c}\text { Brand Image } \\
\text { Recommendation } \\
\text { Intention }\end{array}$ & $\longleftarrow$ & Satisfaction &, 636 & 0,009 \\
\hline
\end{tabular}

$* \mathrm{p}<0,01$ (statistical significance level)

According to Table 4, it is seen that food quality has a positive effect on the brand image $(\beta=.779, \mathrm{p}<0.01)$ and this effect is statistically significant. In line with this result, H1 hypothesis is supported. It can be stated that the positive attitude towards food quality affects the brand image positively, and that one-unit increase in food quality will provide approximately .779-unit improvement in the brand image. It can be seen that similar results have been concluded in the studies of Jin, Lee and Huffman (2012).

According to Table 4, it is seen that food quality has a positive effect on satisfaction ( $\beta=$ $.726, \mathrm{p}<0.01)$ and this effect is statistically significant. In this case, $\mathrm{H} 2$ hypothesis is supported. It is seen that one-unit positive increase in food quality will positively increase the satisfaction by .726. Ryu and Han (2010) put forward that food, service and environmental quality directly affect customer satisfaction in their study where they investigate the emergence of intentions towards fast food restaurants. The findings obtained are consistent with the results of the relevant study.

It is seen that the food quality perceived by the respondents has a positive effect on the recommendation intention $(\beta=.625, \mathrm{p}<0.01)$ and this effect is statistically significant. In line with these results, the $\mathrm{H} 3$ hypothesis is supported. In other words, it can be stated that a positive one-unit increase in food quality will result in a .625-unit positive increase in recommendation intention. Kim, $\mathrm{Ng}$ and $\mathrm{Kim}$ (2009) determined that there is a significant relationship between food quality and recommendation intention in their research on food and beverage spots in universities. In addition, Bujisic, Hutchinson and Parsa (2014) stated 
that every improvement in food quality will lead an increase in customer behavioural intentions.

It has been determined that there is a positive relationship $(\beta=.651, p<0.01)$ between satisfaction and brand image and this relationship is statistically significant. It is seen that one-unit change to be achieved in satisfaction will provide .651-unit change in the brand image. Thus, the alternative hypothesis is rejected and the $\mathrm{H} 4$ hypothesis is supported. Satisfaction positively affects the brand image.

In addition, a statistically significant $(\beta=.836, \mathrm{p}<0.01)$ and positive correlation was found between satisfaction and recommendation intention. Thus, H5 is supported in the hypothesis. It can be expressed that the increase in satisfaction positively affects the recommendation intention.

Finally, there is a positive $(\beta=.269, \mathrm{p}>0.01)$ relationship between the brand image and the recommendation intention, but this relationhip is not statistically significant. In this case, H6 hypothesis is rejected. The increase or decrease in the brand image perception of the respondents does not produce a statistically significant result on recommendation intention.

\section{Result and Discussion}

In this research, the interactions between perceived experience quality factors were tried to be determined. The experience quality dimensions obtained from other studies in the literature on restaurant businesses have been examined from a holistic perspective. In this way, implications were made regarding the food quality, satisfaction, brand image and recommendation intention of the customers in general.

It is seen that the food quality variable under the category of perceived experience quality affects many factors significantly and positively. For this reason, it should be noted that the most important element of the service offered by restaurant enterprises is the food quality. Maintaining standards in food quality increases the customers' satisfaction with the enterprise, the brand image and the recommendation intention. Especially in this study, the intense competition of the restaurant-type enterprises, where the research data were collected, necessitates business managers to make sensitive decisions in this regard. Hwang and Ok (2013) emphasized that the core service that determines the overall restaurant perception of the customers is the food quality. As a matter of fact, the findings acquired in the current study support the findings concluded in the studies of Kim et al. (2009), Ryu and Han (2010), Jin et al. (2012) and Bilgin (2017). 
In this study, it is seen that satisfaction affects the brand image. Han and Hyun (2017) found in their study that the overall image affects satisfaction. Therefore, the obtained findings support the findings in the study of Han and Hyun (2017). In many studies where consumers are characterized as Gen $\mathrm{X}, \mathrm{Y}$, and $\mathrm{Z}$, especially in the marketing literature (Williams and Page 2011; Özaltaş Serçek and Serçek 2016), consumers from Gen Z give importance to the brand image and brand characteristics. Therefore, increased customer satisfaction will positively affect the brand image. In this sense, business owners are required to lead and meet the customer demands in order to increase customer satisfaction.

It is observed that the increase in customer satisfaction increases the likelihood of the business being recommended. The important limitation in qualifying the quality in the service sector is that the service measurement is difficult. The best-known way to overcome this challenge is to listen to other people's recommendations and have comparisons about service, product and enterprise. Therefore, it is important that satisfied customers show positive recommendation intention. It should be assumed that the customers' recommendation behaviour will increase the number of customers visiting the enterprise and thus the business revenue, and efforts should be made to retain existing customers and bring new customers to the enterprise. Thus, both the existing customer profile will be retained, and new customers will be attracted. This result supports the findings in Brunner et al. (2008)'s study.

Although different studies in the literature (Back, 2005; Ryu et al., 2008) revealed that branded cafes, restaurants and other tourism enterprises with a strong corporate image are more likely to be recommended, the findings obtained in this study show that the brand image has no significant effect on recommendation intention.

Customer experience in restaurants can be shaped by the interaction of different elements. Customer satisfaction, brand image and recommendation intention may differ depending on the customers' experiences in restaurants. Creating a high-quality customer experience is important in terms of enabling a loyal customer profile and providing sustainable competitive advantage.

As with any study, this study also employs several limitations. Firstly, the data are obtained from consumers dining in the restaurant enterprise in a limited time period. Secondly, the perceived restaurant experience dimensions are listed as food quality, satisfaction, brand image and recommendation intention, which are addressed in different studies in the literature. However, atmosphere, physical elements, service quality and price elements are not taken into consideration in the scope of the perceived restaurant experience 
quality. Having a holistic approach on the related dimensions in line with the conceptual framework will present important findings to restaurant owners and academicians.

It is suggested that collecting data from consumers who prefer different types of restaurants, what effects the customers' personality traits have on restaurant experience quality dimensions, and examining the variables in terms of service quality, loyalty, atmosphere, physical elements and price element in future studies will contribute to the literature. 


\section{REFERENCES}

Aaker, D.A., \& Jacobson, R. 1994. The financial information content of perceived quality.Journal of Marketing Research, 31(2), 191-201.

Albayrak, A. 2015. Müşterilerin restoran seçimlerini etkileyen faktörler: İstanbul örneği. Anatolia: Turizm Araştırmaları Dergisi, 25(2), 190-201.

Altın, Ş., Çiçek, B. \& Sağlam, K. 2018. "Meslek yüksekokulu öğrencilerinin tüketim alışkanlıklarında marka farkındalığının etkisi” in Z. Arıkan, Ş. Ertekin ve H.Bay. (Editörler), Sosyal Bilimlerde Stratejik Yaklaşımlar, 215-238, Lambert Academic Publishing, Germany.

Altın, Ş., Kurtoğlu, R., \& Kartal, C. 2017. Analysis of the relationship between job satisfaction, burnout, occupational ethics perceptions and organizational commitment of salespersons in the retail sector by structural equation model. International Journal, 5(3), 65-84.

Back, K.2005. The effects of image congruence on customers' brand loyalty in the upper middle-class hotel industry. Journal of Hospitality \& Tourism Research 29(4), 448-467.

Badem, E., \& Öztel, A. 2018. Restoran seçiminde tüketiciyi etkileyen faktörlerin dematel yöntemiyle değerlendirilmesi: bir uygulama. Yönetim Ekonomi Edebiyat Íslami ve Politik Bilimler Dergisi, 3(1), 70-89.

Barta, A. 2008. Foreign tourists' motivation and information source influencing their preference for eating outat ethnic restaurants in Bangkok. International Journal of Hospitality \& Tourism Administration, 9(1), 1-17.

Bayram, N. 2010. Yapısal eşitlik modellemesine giriş- amos uygulamaları, Ezgi Kitapevi, 1. Baskı, İstanbul.

Bekar A.,\& Sürücü, Ç. 2017. The effects of aesthetic value in food an beverage businesses on the aestheticexperiences and revisit intentions of customers. The Journal of Academic Social Science Studies, $1(54), 373-388$.

Bekar, A., \& Gövce, M. 2019. Restoran seçiminde çeşitlilik arama niyeti. Journal of Tourism and Gastronomy Studies, 7(4), 3108-3123.

Bengül, S., \& Güven, Ö. 2019. Yiyecek içecek işletmelerinde fiziksel ortam kalitesi, yiyecek kalitesi ve servis kalitesinin algılanan değer, müşteri memnuniyeti ve müşteri bağlılığı üzerindeki etkisi. Balıkesir Üniversitesi Sosyal Bilimler Enstitüsü Dergisi, 22(42), 375-406.

Bilgin, Y. 2017. Restoran işletmelerinde hizmet kalitesi, müşteri memnuniyeti ve müşteri sadakatinin ağıdan ağıza pazarlamaya etkisi. İşletme Araştırmaları Dergisi, 9(4), 33-62.

Bolton, R.N.,\& Lemon, K.N. 1999. A dynamic model of customers' usage of services: usage as an antecedent and consequence of satisfaction. Journal of Marketing Research, 36(2), 171-186.

Bowden, J. 2009. Customer engagement: a framework for assessing customer-brand relationships: the case of the restaurant industry, Journal of Hospitality Marketing \& Management, 18(6), 574-596.

Brunner, T. A., Stöcklin, M., \& Opwis, K. 2008. Satisfaction, image and loyalty: new versus experienced customers. European Journal of Marketing, 42(9/10), 1095-1105.

Chen ZS. 2001. The strategy of the brand association of thought to the research (the Hong Shen Chin copy chief) of brand rights influence, Management College Journal. 18(1): 75-98.

Clark, M. A.,\& Wood, R. C. 1999. Consumer loyalty in the restaurant industry: A preliminary exploration of the issues. British Food Journal, 101(4), 317-327.

Dobni, D.,\&Zinkhan, G. M. 1990. In search of brand image: A foundation analysis. Advances in Consumer Research, 17(1), 110-119.

Fu, Y.Y.,\& Parks, S.C. 2001. The relationship between restaurant service quality and consumer loyalty among the elderly. Journal of Hospitality \& Tourism Research, 25(3), 320-336.

Gilbert, G.R., Veloutsou, C., Goode, M.M.H.,\&Moutinho, L. 2004. Measuring customersatisfaction in the fast food industry: a cross-national approach.The Journal of Services Marketing, 18(5), 371-83.

Gilbert, G.R.,\& Veloutsou, C. 2006. A cross-industry comparison of customer satisfaction,The Journal of Services Marketing, 20(5), 298-308.

Gül, K.,\& Gül, M. 2016. Fast food restoranlarda marka değeri: Balıkesir'deki yerli ve yabancımenşeli markalara yönelik kıyaslama. Anatolia: Turizm Araştırmaları Dergisi, 27(2), 258-272.

Gülsoy, T. 1999. Reklam terimleri ve kavramları sözlüğ̈̈. Adam Yayınları. İstanbul.

Ha, J., \& Jang, S. 2013. Variety seeking in restaurant choice and 1ts drivers. International Journal of Hospitality Management, 32(2013), 155-168.

Ha, J.,\& Jang, S. 2010. Effects of service quality and food quality: The moderating role of atmospherics in an ethnic restaurant segment. International Journal of Hospitality Management, 29(3), 520-529.

Hair, J. F., Black W. C., Babin B. J. \& Anderson, R.E. 2009. Multivariate Data Analysis, Seventh Edition.

Han, H., \& Ryu, K. 2009. The roles of the physical environment, price perception, and customer satisfaction in determining customer loyalty in the restaurant industry. Journal of Hospitality and Tourism Research, 33(4), 487-510.

Huang, H.C., \& Shanklin, C.W. 2008. An integrated model to measure service management and physical constraints' effect on food consumption in assisted-living facilities. Journal of the American Dietetic Association, 108(5), 785-792. 
Ismail, T. A. T., Muhammad, R., Yusoff, N. M., \& Shariff, M. S. M. 2016. The myth and reality of hotel brand and food quality: the case of hotel restaurants in Malaysia. Procedia-Social and Behavioral Sciences, 222, 382-389.

Jang, S. C., \& Namkung, Y. 2009. Perceived quality, emotions, and behavioral intentions: Application of an extended Mehrabian-Russell model to restaurants. Journal of Business Research, 62(4), 451-460.

Jeong, E., \& Jang, S. 2011. Restaurant experiences triggering positive electronic word-of-mouth (eWOM) motivations. International Journal of Hospitality Management, 30(2), 356-366.

Jin, N., Lee, S., \& Huffman, L. 2012. Impact of restaurant experience on brand image and customer loyalty: Moderating role of dining motivation. Journal of Travel \& Tourism Marketing, 29(6), 532-551.

Kalaycı, Ş. 2009. SPSS Uygulamalı Çok Değişkenli İstatistik Teknikleri, Asil Yayın Dağıtım Ltd., 4. Baskı, Ankara.

Kandampully, J.,\& Suhartanto, D. 2000. Customer loyalty in the hotel industry: the role of customer satisfaction and image. International Journal of Contemporary Hospitality Management 12(6), 346-351.

Karakaş, A., Bilgin, Y., \& Kıngır, S. 2017. Restoran işletmelerinde müşteri memnuniyetinin müşteri sadakatine etkisi: Amasra'da faaliyet gösteren balık restoranları üzerine bir araştırma. Ed. B. Zengin ve O. Özer. In 4th International Congress of Tourism \& Management Researches (600-619).

Keiningham, T., \& Vavra, T. 2001. The customer delight principle: Exceeding customers' expectations for bottom line success. New York: McGraw-Hill.

Kim, W. G., Ng, C. Y. N.,\& Kim, Y. 2009. Influence of Institutional DINESERV on Customer Satisfaction, Return Intention, and Word-ofMouth. International Journal of Hospitality Management, 28(1), 10-17.

Kim., W. G., \& Kim, H.-B. 2004. Measuring customerbased restaurant brand equity. Cornell Hotel and Restaurant Administration Quarterly, 45(2), 115-131.

Lin SW. 2005. The brand image, service quality and consciousness are worth of, the research of customer satisfaction and the relation of the customer loyalty: Take trip industry as an example.The Chin Yi University tourist business department institute. Unpublished Master's thesis.

Mudambi, S. M., Doyle, P., \& Wong, V. 1997. An exploration of branding in industrial markets. Industrial Marketing Management, 26(5), 433-446.

Namkung, Y., \& Jang, S. (2007). Does food quality really matter in restaurants? Its impact on customer satisfaction and behavioral intentions. Journal of Hospitality \& Tourism Research, 31(3), 387-409.

Parsa, H. G., Self, J., Gregory, A., \& Yoon, H. 2012. Consumer behavior in restaurants: Assessing the importance of restaurant attributes in consumer patronage and willingness to pay. Journal of Services Research. 12(2) 30-57.

Peri, C. 2006. The universe of food quality, Food Quality and Preference, 17(1/2), 3-8.

Perry, A. \& Wisnom III, D. 2004. Markanın DNA‘sı, Çev: Zeynep Yılmaz, MediaCat Yayınları, İstanbul.

Pine, I., \& Gilmore, J. H. 1998. Welcome to the experience economy. Harvard Business Review, 76(4), 97-105.

Qin, H., \& Prybutok, V. R. 2009. Service quality, customer satisfaction, and behavioral intentions in fast-food restaurants. International Journal of Quality and Service Sciences, 1(1), 78-95.

Romaniuk, J., \& Sharp, B. 2003. Measuring brand perceptions: Testing quantity and quality. Journal of targeting, Measurement And Analysis For Marketing, 11(3), 218-229.

Rozekhi, N. A., Hussin, S., Siddiqe, A. S. K. A. R., Rashid, P. D. A., \& Salmi, N. S. 2016. The influence of food quality on customer satisfaction in fine dining restaurant: Case in Penang. International Academic Research Journal of Business and Technology, 2(2), 45-50.

Ryu, K., \& Han, H., 2010. Influence of the quality of food, service, and physical environment on customer satisfaction and behavioral intention in quick-casual restaurants: moderating role of perceived price. International Journal of Hospitality Management, 34(3), 310-329.

Ryu, K., Han, H., \& Kim, T. H. 2008. The relationships among overall quick-casual restaurant image, perceived value, customer satisfaction, and behavioral intentions. International Journal of Hospitality Management, 27(3), 459-469.

Ryu, K., Lee, H., \& Kim, G. 2012. The influence of the quality of the physical environment, food, and service on restaurant image, customer perceived value, customer satisfaction, and behavioral intentions. International Journal of Contemporary Hospitality Management, 24(2), 200-223.

Serçek, G. Ö., \& Serçek, S. 2017. X, Y ve Z kuşaklarındaki turistlerin destinasyon imaj algılarının karşılaştırılması. Seyahat ve Otel İşletmeciliği Dergisi, 14(1), 6-19.

Soderlund, M., \& Rosengren, S. 2008. Revisiting the smiling service worker and customer satisfaction. International Journal of Service Industry Management, 19(5), 552-574.

Soriano, D.R. 2002. Customers' expectations factors in restaurants: The situation in Spain, International Journal of Quality and Reliability Management 19(8/9), 1055-1068.

Sulek, J. M. \&Hensley, R. L. 2004. The relative importance of food, atmosphere, and fairness of wait. Cornell Hotel and Restaurant Administration Quarterly, 45(3), 235-247. 
Tabachnick, B. G. \& Fidell, L. S. 2012. Using Multivariate Statistics, Sixth Edition, Copyright By Pearson Education, Inc, Manufactured in the United States of America.

Tsiotsou, R. 2006. The role of perceived product quality and overall satisfaction on purchase intentions. International Journal of Consumer Studies, 30(2), 207-217.

Türksoy, A. 2007. Yiyecek-içecek hizmetleri yönetimi. Ankara. Turhan Kitapevi.

Uslu, A. \& Karabulut, N. A. 2019. Slow food konseptine uygun restoranlarda, algilanan hizmet kalitesinin, markaya yönelik imaj, güven ve sadakate etkisi: Köyceğiz ilçesini ziyaret eden yabancı turistler üzerinde bir araştırma, Elektronik Sosyal Bilimler Dergisi, 18(72), 2166-2181.

Williams, A. 2006. Tourism and hospitality marketing: Fantasy, feeling and fun. International of Contemporary Hospitality Management, 18(6), 482-495.

Yang Y. R. 2006. The research of the server industry brand image.The Fu Ren University. Unpublished Master's thesis.

Yuksel, A. 2001. Managing customer satisfaction and retention: A case of tourist destinations, Turkey. Journal Of Vacation Marketing, 7(2), 153-168.

Zeithaml, V.A., Berry, L.L. \& Parasuraman, A. 1996. The behavioral consequences of service quality. Journal of Marketing, 60(2), 31-46.

Zhang Z. J. 2007. The sneakers brand image of consumer is to the research of customer loyalty influence: The identification of the mode of the line structure equation. Taipei Municipal Education University, Athletics Department Master class. Unpublisshed Master's thesis. 